\title{
The Research Plan: Time for the Evaluation
}

Dear readers,

since the first number of its first volume the European Financial and Accounting Journal has been issued in the framework of research plan Development of Financial and Accounting Theory and its Application in Practice from Interdisciplinary Point of View. Nevertheless, every research project has its prescribed time of solution, so with the last day of passed year 2011 it also terminated seven years journey full of joy and sorrow connected with this research plan. For us, investigators, now it comes time to summarise reached results, evaluation of benefits and elaboration of a final report.

A proposal for each research project is every time submitted with exactly stated objective. Our objective consisted in interconnection of particular levels of scientific research from basic research based namely of model solution of agency costs via determination of cornerstone theoretical postulates toward applied research that shall address three areas - national and international accounting and valuation standards, in empirical studies dealing with development in financial markets and development of accounting variables (and ratios) in the Czech Republic and other countries, in preparation of models of information management and financial decision-making in business sector.

From the point of view of basic research, the main output consists in model of agency costs with the most important agents and principals in Czech economic, political and social environment. In the framework of financial accounting, a primary attention was focused on the field of international harmonization of accounting, then audit issues, mergers and acquisitions, accounting of non-profit organisations and information in accounting. Research team has entered actively through the National Accounting Council into the process of harmonisation and participated in making a lot of interpretations to Czech Accounting Standards. Research in management accounting was concentrated on formation and using management oriented information systems in order to increase an ability of management accounting and to improve the information support for the needs of strategic management. Investigation in the field of corporate 
finance and valuation has resulted mainly in proposal of Czech valuation standards, elaboration of financial decision making methodology, transfer pricing construction and financial analytical study of Czech companies.

However, every result has two sides: formal and content. From the formal point of view, it should be noticed 788 registered publications in Czech Information Register of R\&D Results, including 69 monographs, 289 articles in journals with review process and 430 papers presented at conferences. Our research team has been also participated in organization of scientific conferences and has issued two scientific journals including European Financial and Accounting Journal. For the five years of its existence 79 articles with review process were published in this journal. Some articles have raised the attention of the scientific public and have been cited in other journals, some were used in teaching and some, as it happens, then fell into faded into obscurity. Nevertheless, I would dare say that journal have found his place in the sun.

Finally, the research plan terminated. However, in the same way as our research team does not close its discovery ambitions, does not terminated publishing of European Financial and Accounting Journal. Since 2012 it will be newly issued in the framework of The Institutional Support to Long-term Conceptual Development of Research Institution at the Faculty of Finance and Accounting of the University of Economics, Prague.

prof. Ing. Petr MAREK, CSc.

Editorial board's chairman

European Financial and Accounting Journal

and main investigator of former research plan Development of Financial and Accounting Theory and its Application in Practice from Interdisciplinary Point of View 